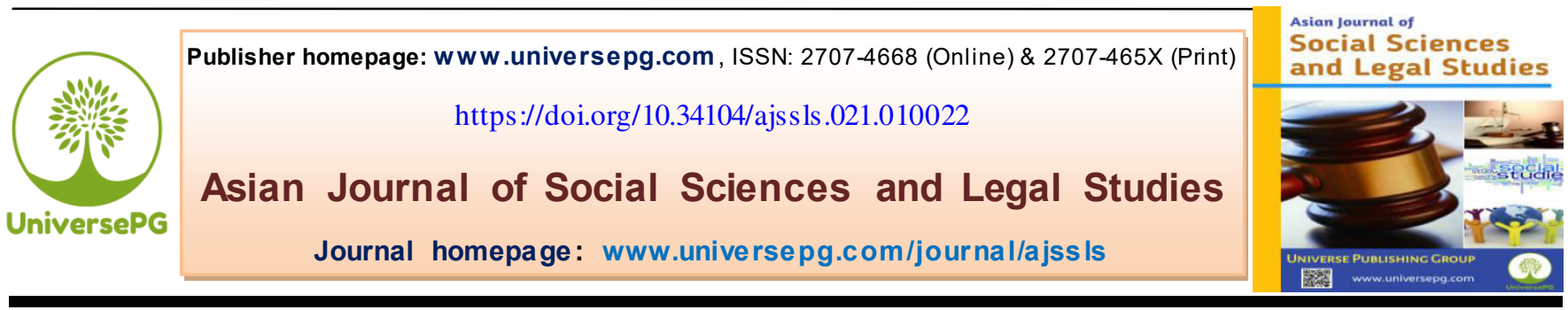

\title{
Exploration of Poverty and Human Rights Violation: A Legal Analysis
}

\author{
Md. Arifuzzaman ${ }^{1 *}$, Farhana Esmay Roquiya Rafee ${ }^{2}$, and Md. Jahurul Islam³ \\ ${ }^{1}$ Department of Law, Green University of Bangladesh, Dhaka, Bangladesh; ${ }^{2}$ Advocate, Judge Court, Dhaka, Bangladesh; and \\ ${ }^{3}$ Advocate, Judge Court, Rajshahi, Bangladesh. \\ *Correspondence: arif@law.green.edu.bd (Dr. Md. Arifuzzaman, Senior Lecturer, Department of Law, Green University of \\ Bangladesh, Dhaka, Bangladesh).
}

\begin{abstract}
In light of human rights, poverty has multidimensional faces, so it is quite complicated to define the term poverty. Some scholars have argued that poverty is a cause and consequence of human rights violation, whereas, rest of others found that poverty itself is a violation of human rights. So it is not clear to what extent poverty violates human rights. This ambiguity leads to some other issues as such, the exact definition of poverty, the approach of human rights, the link between discrimination and poverty, whether the poverty line standard maintains equity, the legal obligations of duty holders, and the human rights approach in incorporate in poverty-reducing plans. All through the world, there are various types of human rights discriminatory laws that exist and which lead to poverty. It can be said that State actions fail to reduce poverty owing to the absence or inadequacy of policies and programs and the lack of appropriate government expenses, in cases where resources are available. This paper is made with the purpose to clarify the term human rights and poverty. It is necessary to draw a link between human rights and poverty. This paper also has some other purposes, such as, try to find out reasons for poverty, giving importance to the duty bearer obligations, and designing the poverty reduction strategies under the human rights approach.
\end{abstract}

Keywords: Poverty, Human rights, Discrimination, Laws, Legal analysis, and International instruments.

\section{INTRODUCTION:}

Poverty is constantly changing issue, so it is quite difficult to ascertain the responsible factors behind poverty. Non-state actors become more influential than states in the national and international arena. The international legal instruments are to reduce poverty using two dominants. The first one identifies with the duty of human rights in international law and other one is considered the role of sovereignty in international law and protects the sovereignty of other States (Al-Amin et al., 2020; Alston and Bhuta, 2005). Sometimes, human rights only defined in a narrow sense with including only civil and political rights.

UniversePG I www.universepg.com
Then, also including the cultural and social rights, it will be outlined in broader concept. Mary Robinson and later from Louise Arbour, UN High Commissioner for Human Rights, have drawn the need of precision within the human rights movement as to the connections between human rights and poverty. Amartya Sen, the Indian economist who introduced an alternative model of poverty through his capability approach theory (Sen, 1976; Islam, 2020).

His under-standing on poverty is that it is not only a deprivation of income, but also a concern regarding powerlessness, voicelessness and social exclusion. Sen defines development as a growth of people's capabi- 
lities (Sen, 1981). To safeguard the human rights from poverty, different poverty reducing approaches are taken in worldwide. Among them one is Millennium Development Goals which is taken in 2000 to fulfill its eight goals (Ligon and Schechter, 2003).

However, MDGs is failure to non-income deprivations, yet three important challenges are lies and to overcome the challenges, a new concept is introduced and that is the Sustainable Development Goal (SDG) (Lawson et al., 2003).

\subsection{Background}

Worldwide, it is well accepted that everyone should respect and protect the fundamental rights of a human being. There is a keen relationship between natural rights and human rights (Kuper, 2000). In addition, some scholars have stated that there is no difference between the two and consider them as being synonymous (Jones and Shahrokh, 2013).

The Universal Declaration of Human Rights (UDHR) helps create a condition where all may enjoy his or her economic, social, cultural, civil and political rights. Article 11 of the International Covenant on Social, Economic and Cultural Rights (ICESCR) ensures a human being's basic necessities. Ultimately, human rights is a moral and legal entitlement of all human beings without discrimination of nationality, residence, sex, religion, origins, color, language or any other status, as stated in the following:

"Everyone has the right to a standard of living adequate for the health and well-being of himself and of his family, including food, clothing, housing and medical care and necessary social services, and the right to security in the event of unemployment, sickness, disability, widowhood, old age or other lack of livelihood in circumstances beyond his control...(Art 25, UDHR)."

Yet, poverty is the symptom of the violation of human rights and its cause. Overcoming severe poverty is not only a charitable gesture but an obligation of human rights. These rights have been protected by various international laws, treaties, customary laws, general principles, as well as national constitutions and legislations (Van, 2010).

UniversePG I www.universepg.com

\subsection{Statement of the problem}

As a human being, we have some basic needs-safe food and water, clothing, shelter, basic medical care and education. Those who suffer from poverty are deprived from such basic needs. Poverty exists in different levels- extreme, moderate and relative, and it is a vow to enhanced short, medium and long term protections of human rights of the poor (CESR, 2008). In poor countries, extreme or absolute poverty mostly exists. Absolute poverty is defined as households that cannot meet their basic survival necessities. Moderate poverty exists in developing countries, and it refers to conditions of life in which basic needs are just barely met (Narayan et al., 2000). Whereas in developed countries, relative poverty - a household income level below a fraction of the average national income, can be found (Costa, 2008). The World Bank has set the same standard for poverty line for all nations, be it developed or developing. In 2015, this standard was updated to 1.90 USD. However, this is neither a fair nor an accurate measure owing to the different costs and conditions in different countries, and it ultimately creates inequity. The following questions will be answered in this paper:

a) What can be the exact definition of poverty?

b) What is the approach of human rights?

c) To what extent does poverty violate human rights?

d) Is there any link between discrimination and poverty?

e) Can poverty line standard be maintaining the equity?

f) What would be the legal obligations of international institutions or duty holders?

g) What would be the human rights approach to incorporate poverty reducing plans?

\subsection{Purpose of the study}

This study has the following objectives:

1) To clarify the definition of human rights and poverty.

2) To draw a relation between human rights and poverty.

3) To determine causes of poverty.

4) To focus on the duties or obligations of duty protectors. 
5) To introduce some poverty reducing plans through a human rights approach.

\subsection{Scope and limitations}

This paper emphases on the issue of poverty under the provisions of the Universal Declaration of Human Rights (UDHR, 1948) and other international human rights regulations. Moreover, this paper seeks to look into different nations' constitutional frameworks and legislations to ensure social justice and basic necessities to their people. In this situation, it is hard to determine the extent of human rights violations under the two different perspectives, i.e. international versus national frameworks. Though many human rights scholars have endeavored to determine the issue of poverty and human rights, there is still a lack of conceptual clarity regarding this matter. The ambiguous information and ideologies create confusion regarding to what extent poverty plays a role in human rights violations. This issue of poverty and human rights is a constantly changing matter. So, it is essential to continuously update the information. Any change that comes into any human rights laws during this research period has been included in this study.

\subsection{Definitions of terms}

Poverty in light of Human Rights - "Poverty is a human condition characterized by the sustained or chronic deprivation of the resources, capabilities, choices, security and power necessary for the enjoyment of an adequate standard of living and other civil, cultural, economic, political and social rights" (UN Office of the Higher Commissioner of Human Rights, Committee on Economic, Social and Cultural Rights).

"Extreme poverty to me is the greatest denial of the exercise of human rights. You don't vote, you don't participate in any political activity, your views aren't listened to, you have no food, you have no shelter, your children are dying of preventable diseases you don't even have the right to clean water. It's a denial of the dignity and worth of each individual which is what the Universal Declaration proclaims (Mary Robinson)."

Chronically Poor - The chronically poor, who often suffer earliest and worst following shocks and dis- asters are also less likely to have risk insurance or safety nets that can support them through hard times (Vakis et al., 2016).

Poverty in light of economics - The World Bank Group defines poverty as US \$1.90 a day.

Right vs. Need - According to the Stanford Encyclopedia of Philosophy, "a right is something which one is entitled to solely by virtue of being a person and it enables an individual to live with dignity". Moreover, rights can be enforced and impose an obligation on the government. A need, in contrast, is a desire that can be to certain degree legitimate, but it is not the government's obligation to meet that need (WB, 2018).

Human Rights - "Human rights as international norms that help protect all people everywhere from severe political, legal, economic, and social abuses; or, alternatively, that serve to secure and preserve extremely important goods, protections, and freedoms in those various areas for all people everywhere" (Nickel, 1987). These rights are now envisaged in the 1948 UDHR and in nine principal international covenants and treaties.

"Everyone has the right to a standard of living adequate for the health and well-being of himself and of his family, including food, clothing, housing and medical care and necessary social services .......(Art. 25)." "Everyone, as a member of society, has the right to social security and is entitled to realization, through national effort and international co-operation and in accordance with the organization and resources of each State ....(Art. 22)."

"Everyone is entitled to social and international order in which the rights and freedoms set forthin this Declaration can be fully realized (Art. 28.)",

Horizontal Inequality - This occurs in socially constructed group, for instance gender, race, religion and caste, language, political or other opinion, national or social origin. It suggests that all human beings deserve equal protection against arbitrary discrimination by public actors under the law.

Vertical Inequality - This occurs between individuals or households within a society. This means the overall 
income or wealth distribution of an economy. It recommends that everybody is equal before the law.

\subsection{Human rights and poverty}

Ultimately, human rights is a moral and legal entitlement of all individuals with no discrimination based on their nationality, residence, sex, religion, origins, color, language or any other status (Ravallion, 1988). However, some have contended that poverty is both the cause and the effect of human rights violations, whereas others have presented the argument that poverty is itself a violation of human rights (Singh and Singh, 2008). Rest of the other believed that freedom from poverty as an independent human right. To answer the question, whether poverty itself is a violation or not relies upon how one characterizes 'human rights' and 'poverty'. If the human rights are defined in a narrow sense and which includes mere civil and political rights, then the correlation with poverty will be designed in one way (CESCR, 2000). Then again, if human rights are defined in consideration of a full range of rights, i.e. cultural, and social, the relationship will be framed in a changed way (Zimmerman and Carter, 2003).

According to Mary Robinson and later from Louise Arbour, UN High Commissioner for Human Rights, have articulated the lack of clarity within the human rights movement regarding the relationships between human rights and poverty (CESCR, 2001). Sometimes, poverty is not treated as a human rights issue and is also seen as an unavoidable tragedy in low- and middle income countries (LMICs). Besides that, those who experience the unpleasant effects of poverty the most are blamed for their predicament since they are frequently portrayed as being lazy, undeserving, or criminals (Muralidhar, 2008). Therefore, their status as a poor person causes them to be treated like they are not worthy of human rights protection (Kanbur and Shaffer, 2007). This facilitates exploitation, discrimination, marginalization and stigmatization against these poverty stricken individuals. As such, they are denied their basic rights and resources. This is a prime demonstration of how poverty causes violation of human rights. The alternate view is that poverty is a result of human rights violations. When an individual's human rights are violated, e.g. eviction from

UniversePG I www.universepg.com their home/ancestral land, or denial of education, or health care, this may leave the person in a dire financial situation. This can perpetuate and reinforce cycles of poverty, which may eventually become chronic.

\subsection{Capability approach}

Amartya Sen, the Indian economist who introduced an alternate model of poverty through his capability approach theory (Sen, 1981). This theory departs from the older understanding of poverty as an income based measure, and introduces the broader conception of human development. His understanding on poverty is that it is not mere a deprivation of income, but also a concern regarding powerlessness, voicelessness and social exclusion. Sen defines development as a growth of people's capabilities. Moreover, he presents the following two arguments:

1) A person requires good health to accomplish their freedom and to not be harmed by others (negative freedom).

2) Governments and societies must empower institutional environments for good health (positive freedom).

In brief, Sen defines poverty as the lack of one individual's necessity to survive within society, and that survival is also related to the contribution and participation in daily social activities. Those who have had their human rights violated may fall into dire financial and / or social situations which cause them to suffer from poverty. This in return, causes their rights to be denied due to systematic exploitation, discrimination, marginalization and stigmatization. Unless an outside force, such as legal entities, step in, the cycle will be reinforced, and perpetuated in a continuous manner through positive feedback. Therefore, Sen's arguments come into play as that people need to be out of poverty so as to be healthy, and defend their own human rights (negative freedom). And legal entities must step in and empower institutions to make sure that those institutions can protect the human rights of everyone (positive freedom).

A human rights approach suggests that poverty is not simply unavoidable nor can be blamed on the poor. Moreover, it needs to identify whether poverty is created by human actions or policy choices. Considering the human rights approach, poverty is not a 
question of fate but an issue of justice. To discard the view that poverty is unavoidable but rather than focus on the factors of poverty existence. In the US, racial, ethnic, and national minorities, especially Latino and African American persons, are disproportionately concentrated in poor residential areas characterized by substandard housing conditions, limited employment opportunities, inadequate access to health care facileties, under-resourced schools, and high exposure to crime and violence.

In the US, in the criminal justice system racial and ethnic minorities have been treated inappropriately. Roughly 3.1 percent of African men, 1.3 percent of Latino men and 0.5 percent of White men are in prison. (Bureau of Justice Statistics) The criminal records of racial and ethnic minorities are more than whites. Besides that, some stigma and legal discrimination also lie in employment, residence, education, public benefits, judicial service and right to vote as well. In Europe, Roma people are the poorest among all and the most deprived. They are discriminated on a daily basis, such as accessing housing, healthcare, education and employment (Human Rights Watch). In Burma, the Rohingya (a Muslim minority group), who force restrictions on movement, employment opportunities, education, marriage and other aspects of daily lives. Moreover, they have faced rude forced labor, arbitrary detention, rape and torture and killings on ethnic and religion grounds. In Bangladesh, certain discriminatory family laws on marriage and divorce push certain women and families into poverty (Shahjalal, 2020). These family laws are treated as barriers of divorce for women than men, lack of direction on maintenance claims and provisions for partition of marital property after divorce and also ignore women's contribution to households. It shows that State actions fail to reduce poverty, due to the absence of inadequacy of policies and programs and the lack of appropriate government expenditure, in cases where resources are available. In present, poverty has become the top issue of the global agenda.

For over 200 years, prominent scientists have been trying to define the term "Poverty" (Costa, 2008).

In the past, poverty was defined as low income. Moreover, some thinkers have argued that poverty was necessary for economic advancement because they UniversePG I www.universepg.com believed that only those who suffered from the poverty would be eager to farm land, work in factories and join armies. They thought that the main motivation for doing such work was to avoid hunger. Poverty is defined under the human rights framework in multiple dimensions which create ambiguity. In light of human rights, there is a conflict regarding the term "poverty". Some argue that poverty is a cause, along with a consequence of human rights violation, whereas others believe that itself it is a violation of human rights. Therefore, it becomes essential to clarify the relation between poverty and human rights concerning human rights law. If human rights include only civil and political rights, then the relationship will be framed in one way. On the other hand, if human rights include the full range of rights (economic and social rights) then it will be framed in a changed way. To build up the conceptual clarity, it is significant to define poverty and human rights and to draw the relation of poverty and human rights.

\section{Inequality and Discrimination}

There is a keen relation between poverty and discrimination is enormous evident in developed countries and developing countries also. The right to equality and the principle of non-discrimination are the most basic elements of international human rights law. Human rights framework offers partial guidance on the inferences of increasing polarized society, whereas still remains the gap. Inequality is measured in different ways such as between individuals, between households, between social groups and between countries (Clark, 2006).

It is categorized in two types- horizontal and vertical inequality. Horizontal inequality occurs into the socially constructed group, such as gender, race, sex, religion and caste, political, language or other opinion, national or social origin. This suggests that all persons are able to get equal protection against capricious and discriminatory by public actors under the law. In contrast, vertical inequality occurs between individuals or households that mean the overall income or wealth distribution of an economy. It suggests that everyone is equal before the law. In the human rights framework, horizontal inequality issues are more strappingly incorporated than vertical ones. In line 
with the human rights principles of nondiscrimination and equality, human rights must not differ on individual's issues, for instance race, gender, nationality, ethnicity or social groups (Balakrishnan and Heintz, 2015).

Nondiscrimination and equality, these two principles are among the most central elements of international human rights law. These are directly pointed the fact that poverty created from discriminatory practices. Equality and nondiscrimination provisions lie in international human rights instruments to protect the human rights.

\section{International Covenant on Civil and Political Rights (ICCPR), 1966}

\section{Article 19}

1. "Everyone shall have the right to hold opinions without interference".

2. "Everyone shall have the right to freedom of expression; this right shall include freedom to seek, receive and impart information and ideas of all kinds, regardless of frontiers, either orally, in writing or in print, in the form of art, or through any other media of his choice".

\section{Article 21}

"The right of peaceful assembly shall be recognized. No restrictions may be placed on the exercise of this right other than those imposed in conformity with the law and which are necessary in a democratic society in the interests of national security or public safety, public order, the protection of public health or morals or the protection of the rights and freedoms of others".

\section{Article 22.1}

"Everyone shall have the right to freedom of association with others, including the right to form and join trade unions for the protection of his interests".

\section{Article 25}

"Every citizen shall have the right and the opportunity, without any of the distinctions mentioned in article 2 and without unreasonable restrictions:

(a) To take part in the conduct of public affairs, directly or through freely chosen representatives;

(b) To vote and to be elected at genuine periodic elections which shall be by universal and equal suffrage and shall be held by secret ballot, guaranteeing the free expression of the will of the electors; (c) To have access, on general terms of equality, to public service in his country. General comment No. 25 (1996): The right to participate in public affairs, voting rights and the right to equal access to public service".

\section{International Covenant on Economic, Social and Cultural Rights (ICESCR), 1966}

\section{Article 15.1}

"The States Parties to the present Covenant recognize the right of everyone:

(a) to take part in cultural life".

\section{Convention on the Elimination of All Forms of Discrimination against Women (CEDAW), 1979}

\section{Articles 7}

"States Parties shall take all appropriate measures to eliminate discrimination against women in the political and public life of the country and, in particular, shall ensure to women, on equal terms with men, the right:

(a) To vote in all elections and public referenda and to be eligible for election to all publicly elected bodies;

(b) To participate in the formulation of government policy and the implementation thereof and to hold public office and perform all public functions at all levels of government;

(c) To participate in non-governmental organizations and associations concerned with the public and political life of the country".

\section{Article 8}

"States Parties shall take all appropriate measures to ensure to women, on equal terms with men and without any discrimination, the opportunity to represent their Governments at the international level and to participate in the work of international organizations".

\section{Convention on the Rights of the Child, 1989}

\section{Article 13}

"1. The child shall have the right to freedom of expression; this right shall include freedom to seek, receive and impart information and ideas of all kinds, 
regardless of frontiers, either orally, in writing or in print, in the form of art, or through any other media of the child's choice.

2. The exercise of this right may be subject to certain restrictions, but these shall only be such as are provided by law and are necessary:

(a) For respect of the rights or reputations of others; or

(b) For the protection of national security or of public order (order public), or of public health or morals".

\section{Article 15}

"1. States Parties recognize the rights of the child to freedom of association and to freedom of peaceful assembly.

2. No restrictions may be placed on the exercise of these rights other than those imposed in conformity with the law and which are necessary in a democratic society in the interests of national security or public safety, public order (ordre public), the protection of public health or morals or the protection of the rights and freedoms of others".

\section{Article 31}

"1. States Parties recognize the right of the child to rest and leisure, to engage in play and recreational activities appropriate to the age of the child and to participate freely in cultural life and the arts.

2. States Parties shall respect and promote the right of the child to participate fully in cultural and artistic life and shall encourage the provision of appropriate and equal opportunities for cultural, artistic, recreational and leisure activity".

\section{States Actions and Policy}

To address poverty, traditionally, the human rights framework is concentrated on the State's responsibility. Whereas poverty issues constantly get involved with other elements, for instance social institutions, private corporations, and actors at the public, regional, national and international level (Heywood, 2009). Thus, it is somewhat difficult to ascertain the responsible factors behind poverty. The state's duty is to safeguard citizens, and prevent violations instigated by the non-state actors. If the actors are not parties of treaties on human rights, then it is tough to hold them directly under human rights regulations. This way, non-state actors become more authoritative than states in the national and international arena (Gready, UniversePG I www.universepg.com
2008). There is a pressure to extend the human rights framework, and in consequence of that, many corporations have agreed to follow the UN Global concept, or the Organization for Economic Co-operation and Development (OECD) Guidelines for Multinational Enterprises (Fujii, 2016). Some other international public actors, such as International Monetary Fund (IMF), the World Trade Organization (WTO), the World Bank (WB), etc., also have a great impact on national policies, and restrain governments from employing human rights remedy (Kraay, 2004).

There are some scholars who believe that these international organizations do have legal entities, and that it is vital to hold them accountable to uphold certain human rights based on their legal obligations (Eswaran and Kotwal. 1990). In certain cases, laws show that it is probable to hold non-state actors accountable for violating the elements that create poverty. However, it does not indicate that the state's duty to protect its citizens is over.

\section{International Actions and Policy}

The international legal instruments are to eradicate poverty using two dominants. The first one tells to the duty of human rights in international law. It protects the human rights that as a human being an individual owes in universal features. Other one is considered the role of sovereignty in international law (Barnfield and Horton, 2009). It protects the sovereignty of other States (Berkman and Kawachi, 2000). However, it does not legally obligate States to take positive initiatives to reduce adverse social and economic conditions of the world. Effective poverty reduction strategy needs international action. International assistance and cooperation help to develop the environment and the poor of developing States can move out from the poverty (Benett, 1995).Under the human rights approach, it is a joint responsibility of States to work vigorously. In addition, the multilateral or bilateral treaties to reduce or eliminate of poverty. In this condition, a developed State should not only frame a poverty reduction strategy in regards of poverty within the domestic jurisdiction and beyond its territory as well (Alston and Bhuta, 2005).

Similarly, a developing State should have a poverty reduction strategy beyond its national strategy also. 
There are some provisions on international assistance and cooperation in human rights instruments are stated as -

\subsection{Charter of the United Nations, 1945}

\section{Article 1.3}

"The Purposes of the United Nations are: ... To achieve international cooperation in solving international problems of an economic, social, cultural, or humanitarian character, and in promoting and encouraging respect for human rights and for fundamental freedoms for all without distinction as to race, sex, language, or religion".

\section{Article 55}

"With a view to the creation of conditions of stability and well-being which are necessary for peaceful and friendly relations among nations based on respect for the principle of equal rights and self-determination of peoples, the United Nations shall promote: (a) higher standards of living, full employment, and conditions of economic and social progress and development; (b) solutions of international economic, social, health, and related problems; and international cultural and educational cooperation; and (c) universal respect for, and observance of, human rights and fundamental freedoms for all without distinction as to race, sex, language, or religion".

\section{Article 56}

"All Members pledge themselves to take joint and separate action in cooperation with the Organization for the achievement of the purposes set forth in Article 55 ".

\subsection{Universal Declaration of Human Rights (UDHR), 1948}

\section{Articles 22 and 28}

"Everyone ... is entitled to realization, through national effort and international cooperation ... of the economic, social and cultural rights indispensable for his dignity and free development of his personality (Art. 22)" and "to a social and international order in which the rights and freedoms set forth [in the Declaration] can be fully realized" (Art. 28).

\subsection{International Covenant on Economic, Social and Cultural Rights, 1966}

Article 2.1

"Each State Party to the present Covenant undertakes to take steps, individually and through international assistance and cooperation, especially economic and technical, to the maximum of its available resources, with a view to achieving progressively the full realization of the rights recognized in the present Covenant by all appropriate means, including particularly the adoption of legislative measures".

\section{Articles 11.2, 15.4, 22 and 23}

"General comments No. 2 (1990): International technical assistance measures (on art. 22 of the Covenant); No. 3 (1990): The nature of States parties' obligations (on art. 2.1 of the Covenant); and No. 8 (1997): The relationship between economic sanctions and respect for economic, social and cultural rights".

\subsection{Convention on the Rights of the Child, 1989}

\section{Article 4}

"States Parties shall undertake all appropriate legislative, administrative, and other measures for the implementation of the rights recognized in the present Convention. With regard to economic, social and cultural rights, States Parties shall undertake such measures to the maximum extent of their available resources and, where needed, within the framework of international co-operation".

\section{Article 24.4}

"States Parties undertake to promote and encourage international co-operation with a view to achieving progressively the full realization of the right recognized in the present article. In this regard, particular account shall be taken of the needs of developing countries".

\subsection{Millennium Development Goal and Sustainable Development Goal}

From 2000 to 2015, through the Millennium Development Goal (MDGs) more than 1 billion people uplifted from extreme poverty. The MDGs achieved certain developments under its eight goals and such are:

MDG 1 Eradicate extreme poverty and hunger MDG 2 Achieve universal primary education MDG 3 Promote gender equality and empower women

MDG 4 Reduce child mortality 
MDG 5 Improve mental health

MDG 6 Combat HIV/AIDS, malaria or other diseases

MDG 7 Ensure environmental sustainability

MDG 8 Develop a global partnership for development

However, approximately one tenth of the global population still survives on below the poverty line. MDG's success in reducing income poverty, but it becomes failure to non-income deprivations, such as basic health services and access to quality education. Besides that, still three important challenges are lies and such are-the depth of remaining poverty, the unevenness in shared prosperity and the obstinate discrepancies in non-income dimensions of development. To meet the challenges, a new concept is introduced and that is the Sustainable Development Goal (SDG). Its target is to reduce social, economic and environmental issues by 2030. It is a broader sustainability agenda than MDGs and it addressing the root causes of poverty and the universal need for development that work for all.

\subsection{Poverty Line Standard}

Poverty line is a standard, which is quite useful when comparing poverty between countries, and to draw a common reference point for poverty at the global level (Davies and Carrin, 2001). It is a useful tool to make contrasts between and within countries over the years. To define poverty line, the most common form of survey are regarding household budgets, which varies mostly in whether they calculate a household's expenses or its needs (Barrientos and Hulme, 2008). Thus, even the most accurate poverty line cannot be an appropriate measure to understand the poverty. This is explained through the following: The principle implies by which poverty is characterized and estimated. The pay level at which these are set is regularly too low according to lodging costs in metropolitan regions. For instance, most poverty levels don't consider the cost of transports in large urban communities. They likewise will in general disregard the incredible expense of water for the people who are not associated with piped systems and need to follow through on significant expenses to water merchants or booths. They frequently have unreasonable suppositions with respect to the expenditure of addressing kids' requirements in metropolitan areas.

\section{Loopholes of Poverty Line}

There are some common flaws in the poverty line. Firstly, to build a poverty line, there needs to be a comparison between space and time, where experts set a minimum income level under which, people will deemed poor. Moreover, it is assumed that worldwide, all prices and consumption habits are same, which would never be a true. Actually, in almost every country, there has been a variation in price and consumption habits by region, city or rural area. Secondly, whether people are capable of meeting their own needs or not. Here, how is it conceivable to fix the income level the same for two groups of people such as, one who are able to meet their own needs and other who relies too low income group (almost in poverty). For example:

For staple, poverty lines will by and large allude to a crate of food that connects to the calories a grown-up consistently (2000 cal.), despite the sort of work that grown-up is doing. Be that as it might, with poor people being frequently engaged with cultivating or building work, the necessary measure of calories might be significantly higher. As regards the goods and services they need, poverty lines just depend on a pay bushel that low income family units really burn-through.

The WB has set the same standard for poverty line for all nations, be it developed or developing. In 2015, this standard was updated to 1.90 USD. In consideration of this poverty line, a high-income or LMICs have already been able to provide universal access of basic needs to their population (Balakrishnan and Heintz, 2015).

However, it turns out to be a problem for LMICs, which need a broader definition of property. Besides, poor countries require totally different tools, policies and definitions of poverty. Yet, the international agencies have mostly inherited rich countries' methods, and used those to measure poverty line, which are always measured in richer environment. However, from the above scenario it is clear that, this is neither a fair nor an accurate measure due to the different costs and conditions in different countries, and it ultimately creates inequity. 


\section{To measure the Poverty}

All the countries within the population are existing huge poverty gaps. There is also an income gap lies between the new middle class, the new rich and the rest of the countries become wider and it has to be considered to draw the poverty line (Harriss, 2005). It is found that poverty states are different from region to region in any country also the people's needs are different in everywhere. Besides that continually the prices differ from the capital to other major cities, mid-size ones, small towns and the countryside. Though it has seen quite clearly the real picture, but not yet to be considered into the measure of poverty lines.

\section{RESULTS:}

\section{Exact definition of poverty}

Based on Amartya Sen's capability approach and the exact definition of poverty should be: Without safety nets, an individual may not be capable of meeting his or her needs for a healthy and happy life, not only based on income, but also political, social and other legal actions and policies as well.

\section{Approach of human rights}

Human rights have a cause approach by which a person can suffer from poverty when his or her human rights are violated. There is the consequence approach by which a person who is poor will have his human rights denied, as they are seen as unworthy of human rights. And lastly, the other approach can be that poverty is a violation of one specific human right.

\section{Extent does poverty violate human rights}

Those who are poor cannot afford legal representation. They might be treated as expendable, and therefore seen as unworthy of human rights. Poor people are often voiceless as well, which urges that they require someone else to advocate on behalf of them. But that very notion robs them of their dignity.

\section{Link between discrimination and poverty}

Discriminatory national legislations lead to human rights violation and generate the poverty. Those who are not part of a visible majority are often persecuted, or denied the right to participate in civilian life.

\section{Poverty line standard be maintaining the equity}

The poverty line is neither a fair nor an accurate measure owing to the different costs and conditions in different countries, and it ultimately creates inequity.

\section{Legal responsibilities of international institutions or duty holders}

Duty holders have the main obligation is to hold State, non-State, public and social actors accountable to uphold the human rights of all people in all their capacity.

\section{Human rights approach to incorporate poverty reducing plans}

Under the human rights approach, to reduce the factors behind poverty, consistency of poverty. It will also focus on the non-income dimensions of poverty. Those who are poor and have had their human rights violated as a result should be able to receive legal counsel and representation to restore what was taken away from them in whatever capacity.

\section{CONCLUSION:}

This study supports the human rights approach that human rights violations are both a cause and effect of poverty because it has more practical implications on public policy and programs, which are addressed to human rights under the poverty reduction plan. To analyze the concept, one must be clear on the idea and term of "poverty". For this objective, the term poverty was described under international legal instruments. Moreover, through Amartya Sen's capability approach draws a broader concept of poverty in this chapter. The paper demonstrates a relationship between inequality and poverty and tries to find out a keen relation between poverty and discrimination. Here, the State's responsibility to address the poverty is discussed because it is enormously evident in both developing and developed countries. Sometimes it is not possible to hold State or non-State actor's accountable for human rights violation. With the assistance of international actions and policies, accountability becomes possible which is one of the greatest effective poverty reduction strategies. Through this research, we can find out some results. Firstly, the definition of poverty based on Amartya Sen's capability approach, should be, without safety nets, an individual may not 
be capable of meeting their needs for a healthy and happy life, not only on the basis of income, but also social, political and other legal actions and policies as well. Secondly, Human rights have a cause approach by which a person can suffer from poverty when their human rights are violated. Thirdly, Poor people are often voiceless which requires someone else to advocate on behalf of them, but that very notion robs them of their dignity. Fourthly, Discriminatory national legislations lead to human rights violation and generate the poverty. Fifthly, the poverty line is not an accurate measure due to the different costs and conditions in different countries, so it creates inequity. Sixthly, Duty holders have the main obligation is to hold State and non-State actors accountable. This paper also focuses on other poverty reduction strategies such as MDGs and SDGs. However, still three challenges lie on the program and one of those is the depth of remaining poverty. As a reduction strategy, a focus on the poverty line standard has found a flaw, which is that it needs to measure poverty in a more comprehensive way to mark it perfect for all. It seems that the clarity of poverty is quite necessary in all perspective. Yet it is a constantly changing issue, thus it requires to be further investigated.

\section{ACKNOWLEDGEMENT:}

Many thanks to the co-authors for their genial support in completion of the research work. I would like to express special thanks and affection to my beloved student Farhana Esmay Roquiya Rafee for her enthuseiastic participation in the work.

\section{CONFLICTS OF INTEREST:}

The authors declared no potential conflicts of the interest with respect to the research work.

\section{REFERENCES:}

1) Alston, P. and Bhuta, N. (2005). 'Human rights and public goods: education as a fundamental right in India', in P. Alston and M. Robinson (eds) Human Rights and Development: Towards Mutual Reinforcement. Oxford: Oxford University Press, pp. 242-65. https://doi.org/10.1093/acprof:oso/97801992846 27.003.0011

UniversePG I www.universepg.com
2) Al-Amin M, Alam S, and Hossain S. (2020). Analysis of the present condition of garment workers' rights and its protection under domestic and international legal framework: Bangladesh perspective, Br. J. Arts Humanit., 2(6), 101-112.

https://doi.org/10.34104/bjah.02001010112

3) Balakrishnan, R and Heintz, J. (2015). How inequality threatens all human rights.

https://www.opendemocracy.net/en/openglobalri ghts-openpage/how-inequality-threatens-all-hum an-rights/

4) Barnfield, L. and Horton, T. (2009). Understanding Attitudes to Tackling Economic Inequality. York: Joseph Rowntree Foundation. https://www.jrf.org.uk/report/understandingattit udes-tackling-economic-inequality

5) Barrientos, A. and Hulme, D. (2008). Social Protection for the Poor and Poorest in Developing Countries: Reflections on a Quiet Revolution. Working Paper 31, Brooks World Poverty Institute, Manchester.

6) Benett, Jonathan, (1995). The Act itself. Oxford: Oxford University Press, New York. https://global.oup.com/academic/product/theact-itself-9780198237914?cc=bd\&lang=en\&

7) Berkman, L. Kawachi, I. (2000). Social epidemiology. New York: Oxford University Press. 382.

https://doi.org/10.1093/ije/30.3.635-a

8) Center for Economic and Social Rights (CESR), (2008). Human Rights and Poverty: Is poverty a violation of human rights? CESR Human Rights Insights No. 1-Draft for comments, p.1.

https://www.cesr.org/sites/default/files/CESR_B riefing_-_Human_Rights_and_Poverty___Draft_

December_2009.pdf

9) CESCR (Committee on Economic, Social and Cultural Rights), (2001). Poverty and the International Covenant on Economic, Social and Cultural Rights E/C.12/2001/10. Geneva: Office of the High Commissioner for Human Rights. https://www.refw orld.org/pdfid/45c30b330.pdf

10) Clark, D. A. (2006). 'Development Studies in the Twenty First Century' in D. A. Clark (ed.), 
The Elgar Companion to Development Studies, Edward Elgar, Cheltenham, pp. xxvi-xli. https://www.e-elgar.com/shop/gbp/the-elgarcompanion-to-development-studies-9781843 764755.html

11) Costa, F. D.(2008). Poverty and human rights: from rhetoric to legal obligations a critical account of conceptual frameworks. Sur Revista Internacional de Direitos Humanos, São Paulo, 4(9), 80-107.

http://socialsciences.scielo.org/scielo.php?script =sci_arttext\&pid=S1806-64452008000100005

12) Davies, P. \& Carrin, G. (2001). Risk-pooling-necessary but not sufficient? Bulletin of the World Health Organization, 79(7), 587. https://apps.who.int/iris/handle/10665/268374

13) Eswaran, M., and A. Kotwal. (1990). Implications of Credit Constraints for Risk Behaviour in Less Developed Economies. Oxford Economic Papers, 42(2): 473-482.

https://academic.oup.com/oep/article-abstract/ 42/2/473/2361336? redirectedFrom=PDF

14) Fujii, T. (2016). Concepts and Measurement of Vulnerability to Poverty and Other Issues: A Review of Literature. ADBI Working Paper 611. Tokyo: Asian Development Bank Institute. Available: 37

https://www.adb.org/publications/concepts-andmeasurement-vulnerability-poverty

15) Gready, P. (2008). 'Rights-based approaches to development: what is the value-added?' Development in Practice, 18(6), 735-47. https://doi.org/10.1080/09614520802386454

16) Harriss-White, B. (2005). 'Destitution and the problem of its politics- with special reference to South Asia', World Development, 33(6), 881-892.

https://doi.org/10.1016/j.w orlddev.2004.09.014

17) Heywood, M. (2009). South Africa's treatment action campaign: combining law and social mobilization to realize the right to health. J. of Human Rights Practice, 1(1), 14 36. https://doi.org/10.1093/jhuman/hun006

18) International Covenant on Economic, Social and Cultural Rights (ICESCR). New York, United Nations, (1966). United Nations General Assembly resolution 2200 (21), UN
GAOR, $21^{\text {st }}$ Session, Supp. No. 16, at 49, UN Doc. A/6316, January 3, 1976.

https://www.un.org/en/development/desa/popula tion/migration/generalassembly/docs/globalcom pact/A_RES_2200A(XXI)_civil.pdf

19) Islam MN. (2020). The impact of human rights violation concerning the status of women and children in Bangladesh: a critical review, Br. J. Arts Humanit., 2(1), 1-13. https://doi.org/10.34104/bjah.02001013

20) Jones, N. and Shahrokh, T. (2013). Social protection pathways: shaping social justice outcomes for the most marginalised, now and post-2015. London. Pp. 1-16.

https://www.odi.org/sites/odi.org.uk/files/odiassets/publications-opinion-files/8390.pdf

21) Kanbur, R. and Shaffer, P. (2007). Epis-temology, Normative Theory and Poverty Analysis: Implications for Q-Squared in Prac-tice. World Development. 35(2), 183-196. https://doi.org/10.1016/j.w orlddev.2005.10.016

22) Kraay, A. (2004). When Is Growth Pro-Poor? Cross-Country Evidence. IMF Working Paper 04-47.

https://www.imf.org/external/pubs/ft/wp/2004/w p0447.pdf

23) Kuper, Andrew (2000). 'Rawlsian Global Justice: Beyond the Law of Peoples to a Cosmopolitan Law of Persons', Political Theory, 28(5), 640-674.

https://www.jstor.org/stable/192292?seq=1

24) Lawson, D., McKay, A. and Okidi, J. (2003). 'Poverty Persistence and Transitions in Uganda: A Combined Qualitative and Quantitative Analysis', CPRC Working Paper 38, Institute for Development Policy and Management, University of Manchester, UK. https://doi.org/10.1080/00220380600884191

25) Ligon, E., and Schechter, L.(2003). Measuring Vulnerability. Economic J, 113: 95-102. https://pdfs.semanticscholar.org/6c8b/c19772f99 11efaa30d468561c9e7da25c2a2.pdf

26) Muralidhar, S. (2008). 'India: the expectations and challenges of judicial enforcement of social rights', in M. Langford (ed.) Social Rights Jurisprudence: Emerging Trends in 
International and Comparative Law. Cambridge University Press, pp. 102-23.

https://delhidistrictcourts.nic.in/ejournals/Social Rights Jurisprudence.pdf

27) Narayan, D. et al. (2000). Voices of the poor: Can anyone hear us. New York: Oxford University Press for the World Bank.

28) Nickel, James. (1987). Making Sense of Human Rights. Berkeley, CA: University of California Press.

https://www.amazon.com/Making-SenseHuman-Rights-Nickel/dp/1405145358

29) Ravallion, M. (1988). Expected Poverty under Risk-induced Welfare Variability. Economic Journal, 98(393): 1171-1182. https://www.jstor.org/stable/2233725

30) Sen, Amartya. (1976). "Poverty: An Ordinal Approach to Measurement." Econometrica. 44. https://doi.org/10.2307/1912718

31) Sen, Amartya. (1981). Poverty and Famines: An Essay on Entitlement and Deprivation. Clarendon Press Oxford, New York.

https://www.prismaweb.org/n1/wp-content/uplo ads/2017/06/Poverty-and-famines $\%$ E2\%94\%82 Amartya-Sen\%E2\%94\%821981.pdf

32) Shahjalal M. (2020). Can 'control-order' be implanted into the counter-terrorism policy of Bangladesh? A critical assessment, Asian J. Soc. Sci. Leg. Stud., 2(3), 63-70. https://doi.org/10.34104/ajssls.020.063070

33) Singh, A.R., and Singh, S. A. (2008). Diseases of Poverty and Lifestyle, Well-Being and
Human Development. Mens Sana Monogr. 6(1): 187-225.

https://doi.org/10.4103/0973- 1229.40567

34) United Nations Committee on Economic, Social and Cultural Rights, (2000). The right to the highest attainable standard of health. Geneva: United Nations; CESCR General Comment 14, document E/C.12/2000/4.

https://digitallibrary.un.org/record/425041? $\ln =\mathrm{e}$ $\underline{\mathrm{n}}$

35) Vakis, R. Rigolini, J and Lucchetti, L. (2016). Left behind, chronic poverty in Latin America and the Caribbean. World Bank. http://hdl.handle.net/10986/21552

36) Van Bueren, G, (2010). Freedom from Poverty as a Human Right, Law's Duty to the Poor, Unesco publishing, p.1.

https://unesdoc.unesco.org/ark:/48223/pf000018 7613

37) World Bank (WB), (2018). Making Growth Work for the Poor: A Poverty Assessment for the Philippines.

http://documents.worldbank.org/curated/en/2736 31527594735491/pdf/126194-WP-REVISEDOUO-9.pdf

38) Zimmerman, F., and Carter, M.(2003). Asset Smoothing, Consumption Smoothing and the Reproduction of Inequality under Risk and Subsistence Constraints. Journal of Development Economics 71: 233-260.

https://www.sciencedirect.com/science/article/pi i/S0304387803000282

Citation: Arifuzzaman M, Rafee FER, and Islam MJ. (2021). Exploration of poverty and human rights violation: a legal analysis, Asian J. Soc. Sci. Leg. Stud., 3(1), 10-22. https://doi.org/10.34104/ajssls.021.010022 @ 